\title{
Factors Influencing the Choice of Higher Education Establishment for Marketing Strategies of Higher Education
}

\author{
Glorija Sarkane ${ }^{1}$, Biruta Sloka ${ }^{2},{ }^{1}$ RISEBA, ${ }^{2}$ University of Latvia
}

\begin{abstract}
The world-wide competition of higher education programs makes education institutions to seek for most efficient ways to attract students. The presented academic research is devoted also to the issues on motives and influencing factors for the choice of study programs. The methods applied in the current paper are as follows: analysis of scientific publications, focus group discussions, surveys of possible future students. For the evaluation of different aspects of choice a scale of 1-10 was used. For the data analysis of the survey descriptive statistical analysis, cross tabulations and correlation analysis, as well as analysis of variance (ANOVA) and factor analysis were applied.
\end{abstract}

Keywords - Choice, higher education programs, marketing, motivation, student expectations.

\section{INTRODUCTION}

The academic research worldwide has paid a lot of attention to the marketing of the higher education, even symposium on Marketing of Higher Education was held in 2006, various scientific publications are published on research results in many internationally recognised scientific journals (Journal of Marketing for Higher Education, Studies in Higher Education, Journal of Applied Research in Higher Education, Research in Post/Higher Education, International Journal of Education Management, Marketing Intelligence and Planning) which are included in solid academic data bases. The reason for such extended attention of researchers as well as education managers is explained by the increasing competition of higher education study programs as annually bigger supply is noticed on the one hand as well as the decrease of number of students on the other hand. Several aspects of marketing of higher education institutions as well as of study programs are under research including the aspects of information and source preferences of the student market in higher education, student recruitment strategies in higher education, strategy in direct and instructive marketing communications, possibility of higher education institution's marketing strategy improving the student-institution match, different aspects of marketing of international education online, emotional connections in higher education marketing, marketing framework in higher education. For the research as well as for marketing strategies development several advanced methods are applied, including different mathematical models and marketing mix approaches.

The aim of the current research is to determine the factors influencing the choice of higher education establishment.

To reach the aim of the current research the following methods were applied: analysis of scientific publications, focus group (higher education institution administrators and responsible persons for higher education institution marketing) discussions, survey of possible students in different regions of Latvia. The evaluations scale 1-10 was used to find out the responses as well as to evaluate the variability of responses.

For the analysis of the data obtained in surveys descriptive statistics, cross-tabulations, as well as methods of multivariate analysis were used: correlation analysis, variance analysis and factor analysis. The results of empirical studies were compared with the theoretical findings of researchers in other countries.

\section{THEORETICAL BACKGROUND}

Researchers already in the last century have found that classical marketing values and findings (Churchill \& Surprenant, 1982), are applicable to great extent also for higher education marketing (Cook \& Zallecco, 1983) and student attitude modelling (Hooley \& Lynch, 1981) as nowadays there is importance for higher education marketing (Ravidran \& Kaplana 2012). For the exchange of scientific findings several significant scientific journals have even been created, like Journal of Marketing for Higher Education, Studies in Higher Education, Research in Post/Higher Education, International Journal of Education Management, etc. Several big international congresses and forums have been devoted to higher education marketing. Several approaches of marketing mix are under thorough research to make marketing as efficient as possible for higher education (Wasmer, et al, 1997), like the four Ps of the marketing concept for higher education establishments (Brownlie, and Saren, 1992) and adjusting concepts of the marketing mix using 4Cs to improve the marketing planning in higher education (Wasmer, et al, 1997). Educators and administrators in higher education institutions often do not recognise that also higher education establishments including universities are on the market place (Bok, 2003) and they have to take into account that students as consumers are part of the higher education market where marketing of higher education establishments has a special role and place (Kozinets, 2002), that the application of marketing knowledge (Rossiter, 2001) and experience and findings of others (Pettie and Pettie, 2003), as well as the possibilities and challenges of marketing international education online (Gomes and Murphy, 2003) are more and more important as education is becoming an export industry in many countries. There has been an extensive research on marketers and educators, which often do not have common 
language and often are considered as different not crossing fields (Gibbs, 2008), with concluding practical recommendations. Emotional connections in higher education marketing, including the contribution to knowledge through graduate employability, international research and interaction with industry as well as the development of marketing concept has grown in importance for universities across the world (Durkin, et al., 2012). Specific approaches in international marketing in the higher education in the UK have been applied on issues in relation to marketing educational programmes to overseas students as well as analysed by the researchers (Kinnel, 2003). Several researchers have questioned whether higher education as a market is a problem or solution (Gibbs, 2001). The experience findings and scientific result sharing goes to the details of the issue like organisation of the marketing process for higher education (Czsikova, et al., 2014), promoting the respective higher education establishment (Muniz and Guinn, 2001) and finding different marketing approaches of higher education (Gibbs, 2002). Factors of a student market in higher education were grouped together with the following labels: university, college, employability aspects, course content, student experience, sporting aspects, financial aspects, direct sources, media sources and social sources. (Bonnema and van der Waldt, 2008). Researchers have investigated the issues by asking the question: can the higher education institution's marketing strategy improve the student-institution match with special attention to information on study program organisation and realisation (Moogan, 2011). The research findings conclude that student recruitment strategies are often grounded in inherent institutional identities, while at the same time the responding to external ideas about excellence and diversity as well as the research results indicate that education institutions show significant creativity in trying to adapt to these ideas and general trends, at the same time maintaining their own characteristics and traditions. The research findings suggest that student recruitment strategies are also used for accountability purposes, but many higher education institutions devote surprisingly little importance to this issue (Frølich and Stensaker, 2010). The global market for higher education has changed significantly and the competition for students force to apply developed and aggressive marketing approaches to attract students (Mazzarol and Soutar, 2012). It is stressed by Naryanan T. Ramachadaran that the marketing theories applied to commercial sector may not be relevant to the higher education sector and that marketing frameworks cannot be transplanted into the higher education environment as the sector is unique and is characterised more by the principles of self-governance and academic freedom, therefore the application of marketing techniques could restrict students' rights and destroy the relationship that exists between the higher education institution and the students - this forces marketing departments to focus on creating mature markets. International group of researchers from the United Kingdom and Germany have studied the aspects of marketing of higher education with special focus on service quality in higher education and the role of student expectations. Students expect their lecturers to be knowledgeable, enthusiastic, approachable, and friendly. The results indicated that students predominately want to encounter valuable teaching experiences to be able to pass tests and to be prepared for their profession. This study also shows that students' academic interests motivate them less than the vocational aspects of their studies, positive perceptions of service quality can lead to student satisfaction and satisfied students may attract new students through word-of-mouth communication and return themselves to the university to take further courses (Vossa, et al., 2007). Researchers suggest that the decision makers at the institutional level and government level seeking to enter these markets must pay attention to the importance of market segmentation and the variables (4Ps) in formulating their marketing strategies (Cheung, et al., 2010). For higher education marketing more and more important are becoming the needs of both students and employers being met by educators and those aspects are examined to a big degree by detailed elaboration (O'Brien and Deans, 1995). The research results have proved that the post-graduate business education market is, and increasingly, getting more aggressive in efforts to attract students, the traditional marketing tools historically grouped into 4Ps (product, price, place and promotion), 5Ps (adding people) and 7Ps (adding physical facilities and processes) have to be considered for the higher education market (Ivy, 2007). An exploration of issues related to the marketing of higher education services is of great importance (Durkin, et al., 2012). Higher education quality has a great importance to attract students, aspects on how excellence and diversity are addressed in student recruitment strategies and how these strategies are developed in Norwegian higher education institutions are on the research agenda of several researchers (Frølich and Stensaker, 2010). The analysis of cross-cultural aspects of the study program selection and expectations are done by Andreas Engelen and Malte Brettel from Germany (Engelen \& Bretten, 2011) who made content analysis of publications related to the issue and compared North American and European results. Different ways of offering studies like e-learning (Dominici \& Palumbo, 2013) and different study fields (Karns, 2005) are on research agenda as well. Several countries apply different marketing communication strategies taking into account political relations, cultural and religion differences, e.g. different aspects of higher education abroad: Palestinian students from Israel studying in Jordanian universities (Arar and Haj-Yehia, 2013), are on the international research agenda and scientific discussions as well.

\section{EMPIRICAL RESEARCH RESULTS}

The main findings of the current research indicate that future students in Latvia in general expect the same as students in other developed countries plus they pay big attention to the prestige of higher education including the higher education obtained abroad. Future students have given the highest importance to the possibility to get a well-paid job, to obtain interesting job, to improve life quality, whereas less important is the family request and the possibility to study 
together with friends as well as employer's request (see Fig. 1).

Possible future students were asked to evaluate factors influencing the selection/choice of their future study institution. The factors for evaluation were included based on the scientific findings of the studies published in scientific journals as well as interviews with higher education administrators and persons responsible for the respective higher education institution and study program marketing and promotion.

More detailed information about the results of survey of possible future students can be seen in Table I.

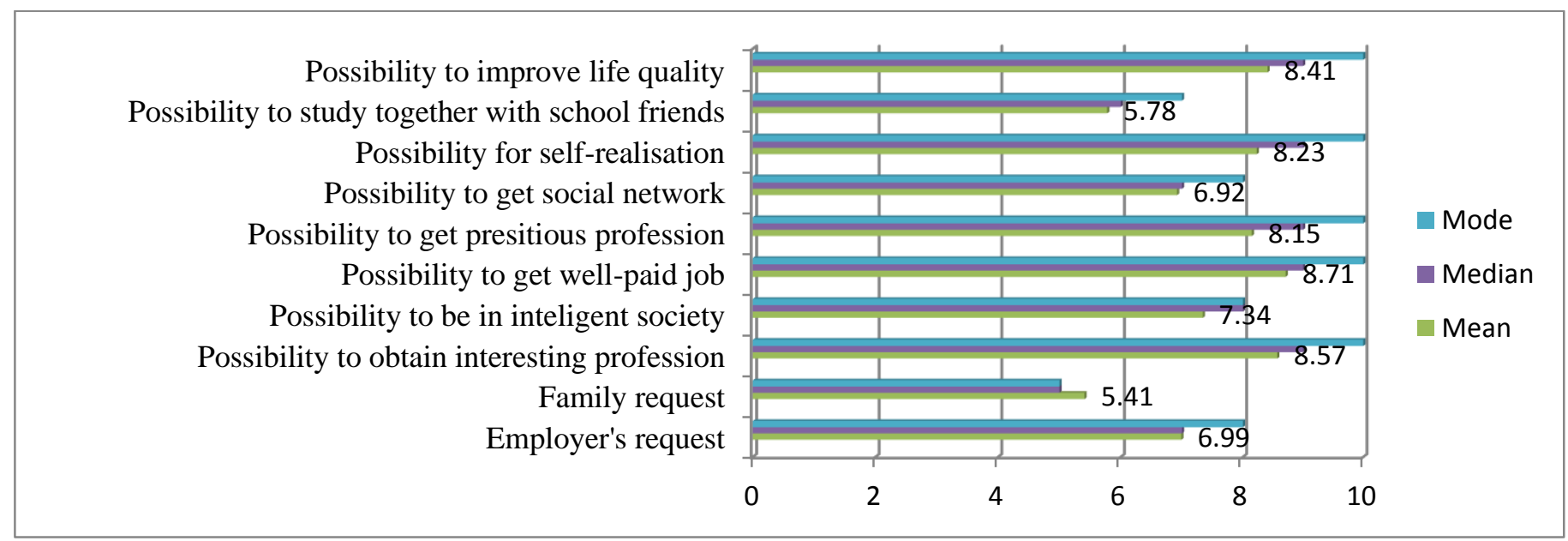

Source: Author's calculations based on secondary school pupils' survey in February - April 2014, $n=669$;

Evaluation scale 1-10, where 1 - not important; 10 - very important

Fig. 1. Secondary school student evaluations of the most important aspects in acquiring higher education.

TABLE I

MAIN STATISTICAL INDICATORS OF EVALUATIONS OF FACTORS INFLUENCING THE CHOICE OF HIGHER EDUCATION ESTABLISHMENT

\begin{tabular}{|c|c|c|c|c|c|c|c|c|c|c|c|c|c|}
\hline & & $\begin{array}{c}\text { Accredita } \\
\text { tion }\end{array}$ & $\begin{array}{c}\text { Atmosph } \\
\text { ere }\end{array}$ & $\begin{array}{l}\text { Place of } \\
\text { location }\end{array}$ & $\begin{array}{c}\text { Activities } \\
\text { outside } \\
\text { studies }\end{array}$ & $\begin{array}{c}\text { State } \\
\text { budget } \\
\text { financing }\end{array}$ & Hostel & $\begin{array}{c}\text { Respect of } \\
\text { confidential } \\
\text { ity }\end{array}$ & $\begin{array}{c}\text { Recommendat } \\
\text { ions of } \\
\text { relatives and } \\
\text { friends }\end{array}$ & Ratings & Reputation & $\begin{array}{c}\text { Sport } \\
\text { possibil } \\
\text { ities }\end{array}$ & $\begin{array}{c}\text { Internatio } \\
\text { nal } \\
\text { possibiliti } \\
\text { es }\end{array}$ \\
\hline \multirow[t]{2}{*}{$\mathrm{N}$} & Valid & 655 & 654 & 653 & 651 & 654 & 654 & 650 & 652 & 651 & 650 & 650 & 655 \\
\hline & Missing & 4 & 5 & 6 & 8 & 5 & 5 & 9 & 7 & 8 & 9 & 9 & 4 \\
\hline \multicolumn{2}{|c|}{ Mean } & 8.19 & 8.11 & 7.62 & 7.09 & 8.23 & 6.17 & 6.96 & 6.66 & 7.67 & 8.02 & 6.72 & 8.16 \\
\hline \multirow{2}{*}{\multicolumn{2}{|c|}{$\begin{array}{l}\text { Std. Error of Mean } \\
\text { Median }\end{array}$}} & 0.077 & 0.059 & 0.072 & 0.078 & 0.079 & 0.106 & 0.087 & 0.083 & 0.076 & 0.073 & 0.099 & 0.076 \\
\hline & & 9 & 8 & 8 & 7 & 9 & 7 & 7 & 7 & 8 & 8 & 7 & 9 \\
\hline \multicolumn{2}{|c|}{ Mode } & 10 & 8 & 8 & 7 & 10 & 8 & 8 & 7 & 8 & 10 & 8 & 10 \\
\hline \multicolumn{2}{|c|}{ Standard Deviation } & 1.979 & 1.508 & 1.831 & 2.000 & 2.031 & 2.699 & 2.220 & 2.114 & 1.946 & 1.872 & 2.532 & 1.952 \\
\hline \multicolumn{2}{|c|}{ Variance } & 3.917 & 2.275 & 3.353 & 3.998 & 4.124 & 7.287 & 4.930 & 4.470 & 3.788 & 3.505 & 6.409 & 3.812 \\
\hline \multicolumn{2}{|c|}{ Range } & 9 & 9 & 9 & 9 & 9 & 9 & 9 & 9 & 9 & 9 & 9 & 9 \\
\hline \multicolumn{2}{|c|}{ Minimum } & 1 & 1 & 1 & 1 & 1 & 1 & 1 & 1 & 1 & 1 & 1 & 1 \\
\hline \multicolumn{2}{|c|}{ Maximum } & 10 & 10 & 10 & 10 & 10 & 10 & 10 & 10 & 10 & 10 & 10 & 10 \\
\hline
\end{tabular}

Source: Authors' calculations based on survey of secondary school pupils in Latvia in February - April 2014, $n=659$;

Evaluation scale 1-10, where 1 - not important; 10 - very important

The empirical results indicated that the most important aspects of getting higher education for possible future students are: possibility to get a well-paid job, possibility to obtain interesting profession, and possibility to improve life quality, but among the aspects important for getting higher education less important were: family request and possibility to study together with school mates.

Although the evaluations of the respondents were different and for all statements covering the full evaluation scale of factors influencing the choice of the higher education establishment the results of the survey indicated that the highest evaluations by possible future students of higher education establishments were given to the factors: state budget financing (arithmetic mean 8.23, mode 10 and median 9), accreditation (arithmetic mean 8.19, mode 10 and median 9), international possibilities (arithmetic mean 8.16, mode 10 and median 9), less important were availability of hostel, recommendations of relatives and friends as well as sports facilities. Surprisingly low average evaluations were for recommendations of relatives and friends, where the arithmetic mean was 6.66 and mode 7 , as well as median 7. It means that already in the last years of secondary school future students are grown up so far that they can make their decisions based on the most important factors influencing their future 
studies. The variability of respondents' views was different and for almost all statements covering all range of the evaluation scale having the biggest differences of views for possibility to stay in hostel (with standard deviation 2.669), sports possibilities (with standard deviation 2.532) and respect of confidentiality (with standard deviation 2.220) and with smaller differences in evaluations for atmosphere (with standard deviation 1.508), place of location (with standard deviation 1.831) and reputation (with standard deviation 1.872). In general views of future possible students were corresponding with the results of theoretical findings of researchers in other countries.

Calculations of the results of factor analysis on the factors influencing the choice of higher education by use of varimax rotation are presented in Table II.

\section{TABLE II}

COMPLEX FACTORS OF CHOICE OF HIGHER EDUCATION ESTABLISHMENT Rotated Component Matrix ${ }^{\mathrm{a}}$

\begin{tabular}{|l|r|r|r|}
\hline \multirow{2}{*}{} & \multicolumn{3}{|c|}{ Component } \\
\cline { 2 - 4 } & \multicolumn{1}{|c|}{1} & \multicolumn{1}{c|}{2} & \multicolumn{1}{c|}{3} \\
\hline Accreditation & -.120 & .326 & .560 \\
Atmosphere & .070 & .155 & .762 \\
Place of location & .197 & -.007 & .626 \\
Activities outside studies & .522 & -.063 & .508 \\
State budget financing & .069 & .403 & .461 \\
Hostel & .767 & .028 & .060 \\
Respect of confidentiality & .615 & .234 & .176 \\
Recommendations of relatives and friends & .650 & .339 & -.1 \\
& & & 49 \\
Ratings & .180 & .840 & .069 \\
Reputation & .177 & .833 & .069 \\
Sport possibilities & .651 & .037 & .108 \\
International possibilities & .053 & .587 & .264 \\
\hline
\end{tabular}

Extraction method: Principal component analysis.

Rotation method: Varimax with Kaiser normalization.

a. Rotation converged in 6 iterations.

Source: Authors' calculations based on survey of secondary school pupils in Latvia in February - April 2014, $n=659$;

Evaluation scale 1-10, where 1 - not important; 10 - very important

The results of factor analysis converged in 6 iterations have indicated that three complex factors out of twelve initial factors indicating evaluations of higher education choice indicators have been created:

Complex factor I - studies support external factor;

Complex factor II - reputation and rating factor;

Complex factor III - internal factor of organization of studies.

The results of the current empirical studies correspond with the theoretical findings as well as with the research results in other countries with surprising difference regarding recommendations of relatives and friends on the selection of higher education establishment.

The results of correlation analysis of factors influencing the choice of higher education institution, age and gender have not shown statistically significant correlation.

\section{CONCLUSION}

Higher education establishments have good fundamentals for the marketing of higher education establishments and programs as serious academic research world-wide have already obtained good theoretical findings confirmed by empirical results of the research on student expectations, attitudes and motivation for studies and for the selection of the respective higher education establishment and study program.

Ignorance or absence of the knowledge of findings of marketing science could lead to problems in student presence in higher education establishments and higher education study programs.

For the future students in Latvia the most important aspects of the choice of higher education establishment are state budget financing, accreditation and international possibilities, whereas less important are availability of hostel, recommendations of relatives and friends, as well as sports facilities. The respective findings are suggested for including in marketing strategies and in the selection of marketing communication tools.

The results of correlation analysis on factors influencing the choice of higher education institution, age and gender have not shown statistically significant correlation and this result could also be suggested for including in marketing strategies and in the selection of marketing communication tools.

The interest in obtaining higher education of future students in Latvia to a great extent corresponds with the theoretical findings of the marketing science.

\section{REFERENCES}

Arar, K., Haj-Yehia, K. (2013). Higher Education abroad: Palestinian Students from Israel Studying in Jordanian Universities. Journal of Applied Research in Higher Education, 5(1), 95-112. http://dx.doi.org/10.1108/17581181311310306

Bok, D. (2003), Universities in the Market Place, Princeton University Press, Princeton, NJ.

Bonnema, J., Van der Waldt, D.I.R. (2008). Information and Source Preferences of a Student Market in Higher Education. International Journal of Educational Management, 22(4), 214-227. http://dx.doi.org/10.1108/09513541211201960

Brownlie, D., Saren, M. (1992), The Four Ps of the Marketing Concept; Prescriptive, Polemical, Permanent and Problematic, European Journal of Marketing, 26(4), 34-47. http://dx.doi.org/10.1108/03090569210012408

Cheung, A.C.K., Yuen, T.W.W., Yuen, C.Y.M, Cheng, Y.C. (2010). Promoting Hong Kong's Higher Education to Asian Markets: Market Segmentations and Strategies, International Journal of Educational Management, 24(5), http://dx.doi.org/10.1108/09513541011055992

Churchill, O.A., Jr., \& Surprenant, C. (1982), An Investigation into the Determinants of Customer Satisfaction, Journal of Marketing Research, 19(4), 491-504. http://dx.doi.org/10.2307/3151722

Cook, R.W., Zallecco, R.L. (1983). Predicting Universities Preference and Attendance: Applied Marketing in Higher Education Administration, Research in Higher Education, 19(2), 197-211. http://dx.doi.org/10.1007/BF00974759

Czikosova, A., Antošova, M, Čukolova, K. (2014). Strategy in Direct and Interactive Marketing Communications, Procedia - Social and Behavioral Sciences, 16, 1615-1619. http://dx.doi.org/10.1016/j.sbspro.2014.01.444

Durkin, M., McKenna, S., Cummins, D. (2012). Emotional Connections in Higher Education Marketing, International Journal of Educational Management, 26(2), 153-161. http://dx.doi.org/10.1108/09513541211201960 
Gibbs, P. (2008), Marketers and Educationalists - Two Communities Divided by Time?, International Journal of Educational Management, 22(3), 269-278. http://dx.doi.org/10.1108/09513540810861900

Gibbs, P. (2002), From the Invisible Hand to the Invisible Hand Shake Marketing Higher Education, Research in Post/Higher Education, 7(3), 323-335.

Gibbs, P. (2001), Higher Education as a Market: a Problem or Solution?, Studies in Higher Education, 26(1), 85-94. http://dx.doi.org/10.1080/03075070020030733

Gomes, L., murphy, J. (2003). An Exploratory Study of Marketing International Education Online. The International Journal of Educational Management, 17(3), 116-125. http://dx.doi.org/10.1108/09513540310467787

Dominici, G., Palumbo, F. (2013). How to Build an E-Learning Product. Business Horizons, 56(1), 87-96. http://dx.doi.org/10.1016/j.bushor.2012.09.011

Engelen, A., Brettel, M. (2011). Assessing Cross Cultural Marketing Theory and Research, Journal of Business Research, 64(5), 516-523. http://dx.doi.org/10.1016/j.jbusres.2010.04.008

Frølich, N., Stensaker, (2010). Student Recruitment Strategies in Higher Education: Promoting Excellence and Diversity?, International Journal of Educational Management, 24(4), 359-370. http://dx.doi.org/10.1108/09513541011045281

Hooley, G.J., Lynch, J.E. (1981). Modelling the Student Universities Choice Process through the Use of Conjoint Measurement Techniques, European Research, 9(4), 158-109.

Ivy, J. (2008). A New Higher Education Marketing Mix: the 7Ps for MBA Marketing, International Journal of Educational Management, 22(2), 4, 288-299. http://dx.doi.org/10.1108/09513540810875635

Karns, G.L. (2005). An Update of Marketing Student Perceptions of Learning Activities: Structure, Preferences and Effectiveness, Journal of Marketing Research, 27(2), 163-171. http://dx.doi.org/10.1177/0273475305276641

Kinnel, M. (1989). International Marketing in UK Higher Education: Some Issues in Relation to Marketing Educational Programmes to Overseas Students. European Journal of Marketing, 23(5), 7-21. http://dx.doi.org/10.1108/EUM0000000000566

Kozinets, R.V. (2002), Can Consumers Escape the Market? Emancipatory Illumination from Burning Man, Journal of Consumer Research, 29, 20-38. http://dx.doi.org/10.1086/339919

Mazzarol, t., Soutar, G.N. (2012). Revisiting the Global Market for Higher Education, Asia Pacific Journal of Marketing and Logistics, 24(5), 717-737. http://dx.doi.org/10.1108/13555851211278079

Moogan, Y.J. (2011). Can a Higher Education Institution's Marketing Strategy Improve the Student - Institution Match? International Journal of Educational Management, 25(6), 570-589. http://dx.doi.org/10.1108/09513541111159068

Muniz, A. and O'Guinn, T.C. (2001), Brand Community, Journal of Consumer Research, 27, 412-32. http://dx.doi.org/10.1086/319618
O'Brien, E., Deans, K.R. (1995). The Position of Marketing Education: a Student Versus Employer Perspective. Marketing Inteligence and Planing, 13(2), 47-52. http://dx.doi.org/10.1108/02634509510083509

Peattie, S. and Peattie, K. (2003), Ready to Fly Solo? Reducing Social Marketing's Dependence on Commercial Marketing Theory, Marketing Theory, 3(3), 365-86. http://dx.doi.org/10.1177/147059310333006

Ramachadaran, N.T. (2010). Marketing Framework in Higher Education: Addressing Aspirations of Students Beyond Conventional Tenets of Selling Products, International Journal of Educational Management, 24(6), 544-556. http://dx.doi.org/10.1108/09513541011067700

Ravidran, S.D., Kaplana, M. (2012). Student's Expectation, Perception and Satisfaction towards the Management Education Institutions, Procedia Economics and Finance, 2, 401-410. http://dx.doi.org/10.1016/S2212-5671(12)00102-5

Rossiter, J.R. (2001), What is Marketing Knowledge? Stage 1: Forms of Marketing Knowledge, Marketing Theory, 1(1), 9-26. http://dx.doi.org/10.1177/147059310100100101

Vossa, R., Gruberb, T. (2007). Service Quality in Higher Education. The Role of Student Expectations, Journal of Business Research, 60(9), 949959. http://dx.doi.org/10.1016/j.jbusres.2007.01.020

Wasmer, D.J., Williams, J.R. and Stevenson, J. (1997), A Reconceptionaization of the Marketing Mix: Using the 4 c's to Improve Marketing Planning in Higher Education, Journal of Marketing for Higher Education, 8(2), 29-35. http://dx.doi.org/10.1300/J050v08n02_03

Glorija Sarkane is currently a PhD student with RISEBA (Riga International School of Economics and Business Administration). She received the Master degree in management from the University of Latvia in 2006. Her major field of study is marketing.

Currently she is a Study Program Director and a Lecturer in marketing at RISEBA. Her research interests are marketing of higher education and promotion channels of higher education study programs. Her previous research interest was in education marketing.

T.: +31722314831

E-mail: Glorija.Sarkane@ riseba.lv

Biruta Sloka, Dr. oec., is a Professor with the University of Latvia. She has participated in several research projects, headed EuroFaculty Riga Centre, has been an advisor to six ministers of economy and an advisor of two ministers of education and science. She is a Member of Latvian Association of Econometrists, Member of Association of Professors of Higher Education of Latvia and the President of Latvian Association of Statisticians.

Address: Faculty of Economics and Management, University of Latvia, 5 Aspazijas Blvd., Riga LV-1050, Latvia

T.: + 37129244966

E-mail: Biruta.Sloka@lu.lv 